\title{
MICP-reinforced soil under three-dimensional grout injection condition
}

\author{
Yang H. ${ }^{1}$, Peng J. ${ }^{2 *}$, Li J. ${ }^{2}$, and Xie G. ${ }^{2}$ \\ ${ }^{1}$ College of Civil Engineering and Architecture, Jinling Institute of Technology, Nanjing 211169, China \\ ${ }^{2}$ Geotechnical Research Institute, Hohai University, Nanjing 210098, China \\ Received: 01/07/2020, Accepted: 04/08/2020, Available online: 21/10/2020 \\ *to whom all correspondence should be addressed: e-mail: peng-jie@hhu.edu.cn \\ https://doi.org/10.30955/gnj.003374
}

\section{Graphical abstract}

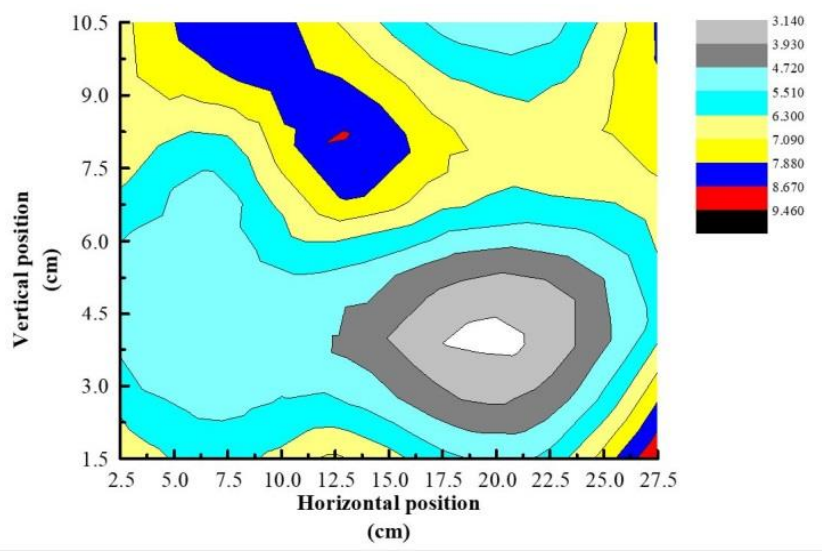

\section{Abstract}

The use of microbial-induced carbonate precipitation (MICP) in soil reinforcement has attracted attention in the academic field in recent years. However, most of the existing studies have been conducted based on onedimensional (1D) grout injection condition. The present study conducted in vitro and sand column experiments of MICP using a ureolytic bacterium (ATCC 11859) (threedimensional $(3 D)$ and $1 D$ models were considered in the sand column experiments) as well as the feasibility and reinforcing effect of the $3 D$ MICP grout injection method. A comparison of the $3 D$ and $1 D$ grout injection methods showed that the specimens reinforced using the $3 D$ grout injection method had higher strength, better homogeneity, a greater $\mathrm{CaCO}_{3}$ content, and a larger permeability coefficient compared with the specimens reinforced using the $1 D$ grout injection method. The limitations of the $1 D$ model should be considered in future practical applications.

Keywords: $\mathrm{MICP}$, grouting method, $\mathrm{CaCO} 3$ content, reinforcing effect, three-dimensional model.

\section{Introduction}

Soil reinforcement is an important topic in the geotechnical engineering field. Conventional soft foundation reinforcement methods, such as preloading consolidation and chemical grout injection, are generally disadvantageous due to long construction periods, high energy consumption, and high costs. In addition, the majority of grouts used in the chemical grout injection method are harmful to the environment (DeJong et al., 2010). With requirements for sustainable and environmentally friendly development being introduced by various countries, ecological environmental protection and energy conservation should be given more consideration when selecting soil reinforcement methods. Under this background, the application of microbial-induced carbonate precipitation (MICP) in soil reinforcement has been receiving attention and is being investigated increasingly more.

MICP, referring to the process of calcium carbonate $\left(\mathrm{CaCO}_{3}\right)$ synthesis, in which the metabolites of a specific bacterium react with matter in the surrounding environment (DeJong et al., 2013; Mohammad Khari, 2019). For example, ureolytic microorganisms generate urease over the metabolic procedure. To increase the $\mathrm{pH}$ of the surrounding solution, the urease catalyzes the hydrolysis of the urea and induce the formation of ammonium icons and carbonate icons ( $\mathrm{CO}_{3}^{2-}$ ions). There are negative charges on the bacterial surface, offering opportunities for the absorption of calcium icons. Combined with cells, structure of crystal nuclei exists once oversaturated $\mathrm{CO}_{3}^{2-}$ and $\mathrm{C}_{a}^{2+}$ ions form $\mathrm{CaCO}_{3}$ crystals in the surroundings (Ivanov and Chu, 2008; Rawat, 2020) (Figure 1).Within the MICP process, $\mathrm{CaCO}_{3}$ crystals fill the pores in the soil and cement soil particles together, along with reinforcing the soil by increasing the strength of the soil, reducing the porosity of the soil, and decreasing the permeability coefficient of the soil and hence it can be considered as an excellent cementing material (Cheng and Cord-Ruwisch, 2014; Choi et al., 2016).

Since Boquet et al. (1973) used the bacteria Bacillus genus and Pseudomonas aeruginosa to induce the formation of $\mathrm{CaCO}_{3}$ precipitates in the laboratory for the first time, the following few types of microorganisms have all been discovered to have the capacity to form $\mathrm{CaCO}_{3}$ precipitates: 
ureolytic microorganisms (e.g., Sporosarcina pasteurii (S. pasteurii)), denitrifying microorganisms, sulfate-reducing microorganisms, and iron-reducing microorganisms (Hammes and Verstraete, 2002; Whiffin, 2004). Researchers have studied the application of various types of microorganisms to repair historic buildings and brick material surfaces, to repair cracks on granite and concrete objects, and for seepage control (Jiang et al., 2017; Jiang and Soga, 2017; Ramachandran et al., 2001). Whiffin (2004), (Achille and Enow, 2020) used MICP in soil reinforcement for the first time. Whiffin used $S$. pasteurii to induce the precipitation of $\mathrm{CaCO}_{3}$ in loose sand. The $\mathrm{CaCO}_{3}$ precipitates significantly increased the shear strength of the sand. DeJong et al. (2010) used X-ray diffraction (XRD) to determine that the cementing material between the sand particles was $\mathrm{CaCO}_{3}$ crystals in calcite form. Later, researchers further investigated the application of MICP in soil reinforcement (Abdikar et al., 2018; Lu et al., 2010). Because the existing research results demonstrate that ureolytic microorganisms are advantageous due to their excellent adaptability to the environment, their capacity to produce large amounts of $\mathrm{CaCO}_{3}$, and their ability to precipitate $\mathrm{CaCO}_{3}$ at high rates (De Muynck et al., 2010; Mortensen et al., 2011), ureolytic microorganisms have become the microorganisms most used in studies that investigate the use of MICP in soil reinforcement.
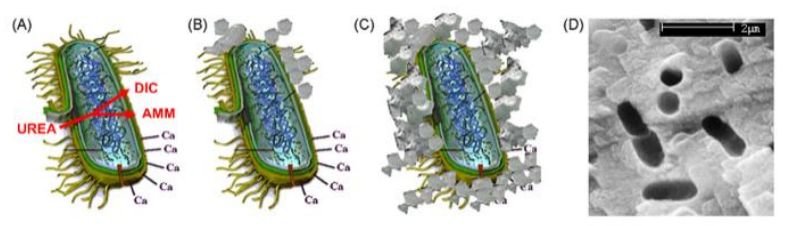

Figure 1. Figure of MICP

It can be observed from Figure 1, DIC and AMM are released in the micro-environment of the bacteria due to the additional urea (A). Calcium carbonate precipitate heterogeneously on the cell wall of bacteria based on the appearance of calcium icons induced local super saturation (B). Then the whole cell was encapsulated (C), resulting in the limitation of the nutrition supply and the death of the cell. Figure $1 D$ depicts the imprints of bacterial cells involved in carbonate precipitation (De Muynck et al., 2010).

It remains challenging to develop effective method to transport microorganisms and the relevant chemical reagents (e.g., urea and $C_{a} C L_{2}$ ) to soil where in need of reinforcement, shedding lights of MICP usage in soil reinforcement (Gomez et al., 2017; Sari, 2015; Soon et al., 2012). Initially, researchers directly mixed a microorganism suspension with chemical reagents and injected the mixed solution into the soil. However, it was found that the mixed solution rapidly flocculated, and crystal precipitates were formed, resulting in the blockage of the pores in the soil near the injection point, which, in turn, obstructed further injection of the mixed solution. Whiffin et al. (2007) proposed a two-phase grout injection method in which solutions are injected separately and successively: to begin with, the soil is injected with bacteria solution, following by fixation solution injection (e.g., $50 \mathrm{mM}, C_{a} C_{2}$ solution); the chemical reagents needed to form precipitates are added in the last step. A portion of the bacteria injected at first is retained in the soil due to adsorption and filtration. After the fixation solution is injected, because they carry positive charges, $C_{a}^{2+}$ ions are more easily adsorbed onto the soil particle surface that carries negative charges. In addition, $C_{a}^{2+}$ ions can also adsorb bacteria that carry negative charges. Therefore, $C_{a}^{2+}$ ions have a certain fixation effect. Using the two-phase grout injection method, Whiffin extended the effectively treated sand column length to $5 \mathrm{~m}$. Later, many researchers improved the two-phase grout injection method. Cheng et al. (2012; 2013), (Gelleh et al., 2018) directly sprayed the bacterial solution and chemical reagents onto the specimen surface successively to reinforce the unsaturated soil. While studying the use of MICP in tropical residual soil reinforcement, Soon et al. (2013) transported the nutrient solution using a pressure pump. Thus far, the related studies were all based on onedimensional (1D) experiments, which may be relatively significantly different from actual engineering applications. van Paassen (2010) conducted a large-volume $(8 m \times 5.6 m \times 2.5 m$ MICP experiment). The authors repeatedly injected the bacterial solution and reagents successively at one side and used a pumping well to transport the bacterial solution and reagents at the other side. A reinforced body with a volume of approximately $100 \mathrm{~m}^{3}$ was formed. However, this study only performed $1 D$ experiments. Clearly, the grout injection method in actual engineering is not a $1 D$ problem. Therefore, studying the three dimensions of the MICP solution and relevant chemical reagents, the three-dimensional (3D) grout injection method and its reinforcing effect, and the difference between the $3 D$ and $1 D$ grout injection methods has important theoretical and application value for guiding the future practical application of MICP.

To study the $3 D$ grout injection method and its effectiveness, the present study conducted $3 D$ and $1 D$ model chamber experiments to investigate the use of MICP in soil reinforcement and comparatively investigate the reinforcing effect and grout consumption of the $3 D$ and $1 D$ grout injection methods. The results showed that it was feasible to use MICP in $3 D$ sand reinforcement. Compared with the 1D-reinforced specimens, the 3D-reinforced specimens had higher strength, a higher $\mathrm{CaCO}_{3}$ content, and better homogeneity. The $3 D$ grout injection method had a better overall reinforcing effect than the $1 D$ grout injection method. Recent studies provide insightful information for the improvement of MICP application in practical engineering in the future.

\section{Material and methods}

\subsection{Bacteria}

S. pasteurii (ATCC 11859) was grown at $30^{\circ} \mathrm{C}$ in a culture medium ATCC 1376, which contained the following per liter of deionized water:0.13 $\mathrm{mol}^{-1}$ tris-3 buffer $(p H=9.0), 10 \mathrm{gL}^{-1}$ 
$(\mathrm{NH} 4)_{2} \mathrm{SO}_{4}$ and $20 \mathrm{gL}^{-1}$ yeast extract. The ingredients were autoclaved separately and mixed together post sterilization. The culture medium was inoculated with the S. pasteurii stock culture and incubated aerobically at $30^{\circ} \mathrm{C}$ in a shaking water bath with 200 rev min-1 for approximately $40 \mathrm{~h}$ before harvesting at a final optical density $\left(O D_{600}, 600 \mathrm{~nm}\right)$ of $0.8-1.2\left(10^{7}-10^{8} \mathrm{cell} / \mathrm{ml}\right)$ (Al Qabany et al., 2012; Aunsary and Chen, 2019). The bacteria and growth media were stored in centrifuge vials at $4^{\circ} \mathrm{C}$ until used (Mortensen et al., 2011).

\subsection{Cementation media}

In recent studies, a mixed urea- $C_{a} C L_{2}$ solution was used as the cementation media. Urea, the nitrogen source, was mainly responsible for microorganism growth, while $C_{a} C L_{2}$ was the calcium source during the MICP process (Arslan et al., 2018; Martinez et al., 2013; Mortensen et al., 2011). Table 1 summarizes the components, concentrations and sterilization methods. All the components, concentrations and sterilization methods are listed in Table 1.

Table 1. Recipe of cementation media

\begin{tabular}{ccccc}
\hline Chemical name & Chemical concentration $(\mathbf{m M} / \mathbf{L})$ & Sterilization & Molar mass & Amount $(\mathbf{g} / \mathbf{L})$ \\
\hline Urea & 1500 & Filter & 60.06 & 90.09 \\
\hline $\mathrm{NH}_{4} \mathrm{Cl}$ & 187 & Autoclave & 53.49 & 10.00 \\
\hline $\mathrm{Tris}$ & 82.5 & Autoclave & 121.14 & 10.00 \\
\hline $\mathrm{CaCl}$ & 500 & Autoclave & 110.98 & 55.49 \\
\hline Nutrient Broth & $3 \mathrm{~g} / \mathrm{L}$ & Autoclave & - & - \\
\hline
\end{tabular}

\subsection{Sand}

China standard sand (medium sand) was used in presented study. Weighing 300 grams of standard sand, the test of particle analysis was performed. Figure 2 shows the grading curve of the sand. The sand had a particle diameter $\left(d_{50}\right)$ of $0.64 \mathrm{~mm}, d_{60}$ of $0.80 \mathrm{~mm}$, uniformity coefficient $\left(C_{u}\right)$ of 5.33 and curvature coefficient $\left(C_{c}\right)$ of 1.33 , the grading of which is good. Before the experiment, the sand was immersed in water and vacuum saturated.

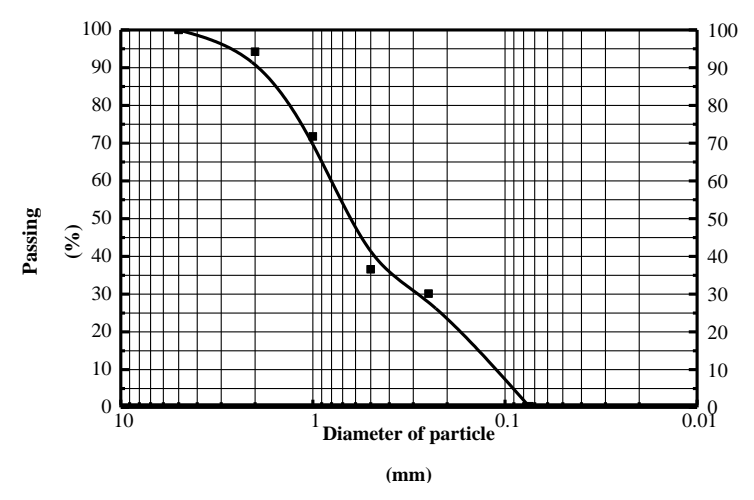

Figure 2. Grading curve

\subsection{Model test}

The model experiments conducted in the present study included $1 D$ and $3 D$ model chamber experiments. The $1 D$ model tank was a cylindrical (polymethyl methacrylate) (PMMA) tube with an internal diameter of $5 \mathrm{~cm}$ and a height of $17 \mathrm{~cm}$. There was an opening at the top of the tube. The location of the grout injection point is shown in the Figure 3. There was a water outlet at the center of the bottom of the $1 D$ model chamber. The $3 D$ model consisted of a $17 \mathrm{~cm} \times 30 \mathrm{~cm} \times 5 \mathrm{~cm}$ (inner dimensions) model chamber that was made from PMMA. There was an opening at the top of the $3 D$ model chamber. During the grout injection process, there were three grout injection points on the upper surface of the $3 D$ model chamber (Liu, 2018; Okpoli and Iselowo, 2019). The locations of the grout injection points are shown in the Figure 3 . The left and right grout injection points were both $10 \mathrm{~cm}$ from the midline. The third grout injection point was located on the midline. There were three water outlets at the bottom of the $3 D$ model chamber. The locations of the water outlets corresponded to those of the grout injection points. The $1 D$ model chamber was used to study the reinforcing effect of MICP under different temperature conditions. The $3 D$ model chamber was used to study the reinforcing effect of the $3 D$ grout injection method.

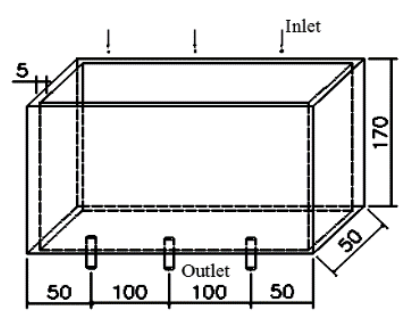

(a)Three-dimensional model chamber ( $\mathrm{mm}$ )

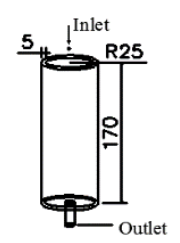

(b)One-dimensional model chamber (mm)
Figure 3. Figure of model chamber device

In the $1 D$ experiment, the pore volume of the sand column was $87.06 \mathrm{ml}$, and the total volume of the bacterial solution injected was $307 \mathrm{ml}$. In the $3 D$ experiment, the pore volume of the sand sample was $633.44 \mathrm{ml}$, and the total volume of the bacterial solution injected was $2290 \mathrm{ml}$. In both the $3 D$ and $1 D$ experiments, the volume of the cementing solution used was the same as that of the bacterial solution used.

\section{Measure methods}

\subsection{Urease activity}

After mixing of $1.0 \mathrm{~mL}$ bacteria solution and $9.0 \mathrm{~mL} 1.60 \mathrm{M}$ urea solution, conductivity was monitored under different temperatures for 5 mins using a conductivity meter. The actual conductivity variation rate $(\mathrm{mS} / \mathrm{min})$ is the measured conductivity variation rate multiplied by the dilution factor. The dilution factor is defined as the ratio of original bacteria concentration to the bacteria concentration after mixing with urea solution. The actual conductivity variation rate can be converted to urea hydrolysis rate $(\mathrm{mM}$ urea hydrolyzed/min), based on a correlation that $1 \mathrm{mS} / \mathrm{min}$ 
corresponds to a hydrolysis activity of $11 \mathrm{mM}$ urea/min in the measured range of activities. This urea hydrolysis rate is the urease activity (Whiffin, 2004). Specific urease activity ( $\mathrm{mM}$ hydrolyzed urea/min/OD) can be calculated by dividing urease activity by bacteria biomass $\left(O D_{600}\right)$, which reflects the urease catalytic ability of urea hydrolysis.

specific urease activity (mMurea hydrolyzed/min/OD

$$
=\frac{\text { urease activity }(\mathrm{mMurea} \text { hydrolyzed } / \mathrm{min})}{\text { Biomass }\left(\mathrm{OD}_{600}\right)}
$$

In accordance with Equation (1), due to urea hydrolysis catalyzed by urease, icon concentration rises with the increasing of the electrical conductivity of the solution, which is proportional to the concentration of active urease. The growth of electrical conductivity rate reflects the hydrolysis rate of urea, describing the urease activity of bacteria solution (Whiffin, 2004).

\subsection{Unconfined compressive strength}

The unconfined compressive strength is an important index that evaluates the reinforcing effect on a specimen. To study the reinforcing effect at different locations, each specimen was divided into several pieces, each of which was then subjected to an unconfined compressive strength test. For the $3 D$ model chamber (Figure 4 ), the specimen was divided into $12 \mathrm{small}$ specimens. For the $1 D$ model chamber, the specimen was divided into two small specimens. Each small specimen was then subjected to a compression test on an unconfined compressive strength tester.

\section{3. $\mathrm{CaCO}_{3}$ content}

In the test tube experiments, the amount of $\mathrm{CaCO}_{3}$ that precipitated in each test tube was measured using the drying method. The upper portion of the liquid in each test tube was removed. The lower portion in each test tube was rinsed with distilled water several times, and then, the clear liquid was removed (Liu and Baghban, 2017). The precipitates were retained and dried in an oven $\left(200^{\circ} \mathrm{C}\right)$ to allow the ammonium chloride and urea that existed in the precipitates to decompose and evaporate. The difference in the mass of the test tube before and after the drying process was the mass of $\mathrm{CaCO}_{3}$.

Table 2. Unconfined compressive strength of samples

\begin{tabular}{cccc}
\hline Samples & Strength $\left(\boldsymbol{k} \boldsymbol{P}_{a}\right)$ & Samples & Strength $\left(\boldsymbol{k} \boldsymbol{P}_{a}\right)$ \\
\hline $1-1$ & 294.7 & $4-2$ & 72.9 \\
\hline $1-2$ & 82 & $5-1$ & 275.3 \\
\hline $2-1$ & 83.6 & $5-2$ & 108 \\
\hline $2-2$ & 81.2 & $6-1$ & 122.8 \\
\hline $3-1$ & 185.2 & $6-2$ & 137.4 \\
\hline $3-2$ & 61.2 & $\mathrm{~A}$ & 165.1 \\
\hline $4-1$ & 161.2 & $\mathrm{~B}$ & 82.1 \\
\hline
\end{tabular}

Table 3. $\mathrm{CaCO}_{3}$ content of three-dimensional samples

\begin{tabular}{ccccccc}
\hline $\begin{array}{c}\text { Position away from the } \\
\text { bottom of the specimen }(\mathbf{c m})\end{array}$ & $\# \mathbf{I}$ & \#II & \#III & \#IV & \#V & \#VI \\
\hline 10.5 & 6.88 & 8.66 & 7.13 & 5.23 & 5.16 & 7.98 \\
\hline 7.5 & 6.61 & 5.37 & 8.83 & 7.14 & 6.85 & 7.19 \\
\hline 4.5 & 4.92 & 4.99 & 4.70 & 3.14 & 3.39 & 5.71 \\
\hline 1.5 & 6.87 & 5.91 & 7.25 & 5.75 & 5.77 & 9.46 \\
\hline Average & 6.32 & 6.23 & 6.98 & 5.35 & 5.29 & 7.74 \\
\hline
\end{tabular}

Note: For ease of comparison with one-dimensional $\mathrm{CaCO}_{3}$ content, in three-dimensional samples, according to Figure 4, 1-1 and 1-2 named \#I sample, and so on. In other words, \#I sample is divided into two parts (1-1 and 1-2)

In the 1D MICP sand column experiments, the acid washing method was used to determine the $\mathrm{CaCO}_{3}$ content of each reinforced specimen. Specimens were crushed by a mortar and oven-dried. The dry soil was washed in HC1 solution $(0.1 \mathrm{M})$ to dissolve precipitated carbonates, then rinsed, drained, and oven-dried. The weight of precipitated $\mathrm{CaCO}_{3}$ in specimen was calculated as the difference between the two weights mentioned before (Rebata-Landa and Santamarina, 2006).

\subsection{Permeability}

The permeability coefficient of each sand specimen was directly measured in the sand column container using a variable head permeability test device.

\section{Results and analysis}

4.1. The strength of MICP-reinforced soil and amounts of $\mathrm{CaCO}_{3}$

Table 2 lists the unconfined compressive strength of the $1 D$ - and 3D-reinforced specimens. It can be observed from Table 2 that the unconfined compressive strength of the top section of a specimen was greater than that of the bottom section of the specimen regardless of it being a $1 D$ or $3 D$-reinforced specimen. In addition, the unconfined compressive strength of the $3 D$ MICP-reinforced specimens were greater than that of the $1 D$ MICPreinforced specimens (Figure 5).

For each $3 D$-reinforced specimen, small portions were removed from the specimen at locations that were 1.5, 4.5, 
7.5 , and $10.5 \mathrm{~cm}$ from the bottom of the specimen in the vertical direction to determine the $\mathrm{CaCO}_{3}$ content of the specimen. For each $1 D$-reinforced specimen, small portions were removed from the specimen at locations that were 2 , $4,6,8$, and $10 \mathrm{~cm}$ from the bottom of the specimen in the vertical direction to determine the $\mathrm{CaCO}_{3}$ content of the specimen. Figure 5 and Table 3 show the $\mathrm{CaCO}_{3}$ content distributions of the $1 D$ - and $3 D$-reinforced specimens, respectively.

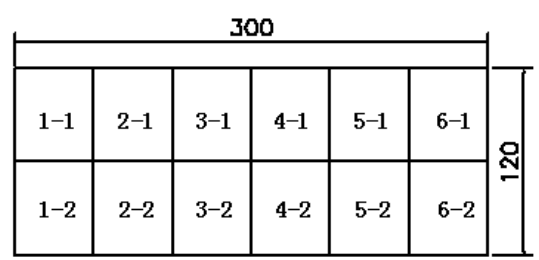

(a)Three-dimensional samples ( $\mathrm{mm}$ )

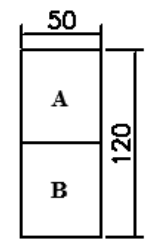

(b)One-dimensional samples ( $\mathrm{mm}$ )

Figure 4. Figure of sample segmentation

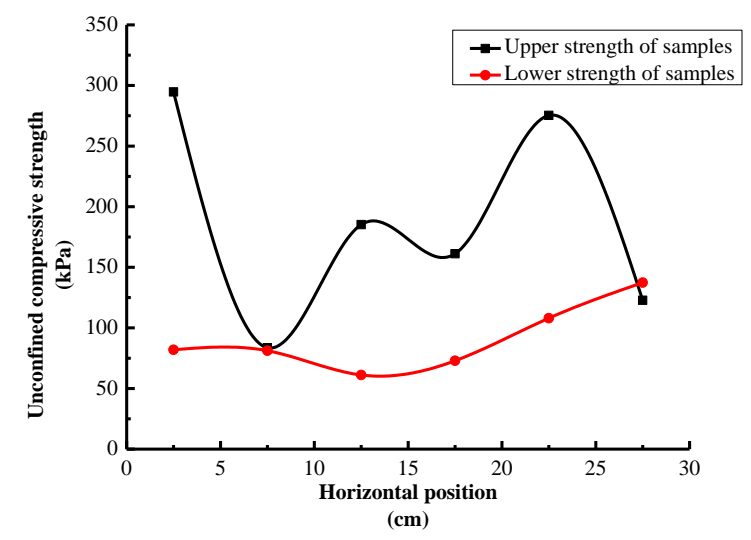

Figure 5. Unconfined compressive strength of threedimensional samples

It can be observed from Figure 6 that for each $1 D$ reinforced specimen, the $\mathrm{CaCO}_{3}$ content in the top section was essentially consistent with that in the bottom section, whereas the $\mathrm{CaCO}_{3}$ content in the central section was the highest and close to twice that in the other section. The $\mathrm{CaCO}_{3}$ content had a relatively significant uneven distribution in each $1 D$-reinforced specimen. It can be observed from Table 3 that the $\mathrm{CaCO}_{3}$ content was not as unevenly distributed in the $3 D$-reinforced specimens compared with the uneven distribution in the $1 D$ reinforced specimens, and there was no sharp change in the $\mathrm{CaCO}_{3}$ content in any of the 3D-reinforced specimens (Kang et al., 2018), which indicates that the $\mathrm{CaCO}_{3}$ formed in each 3D-reinforced specimen was more evenly distributed than that formed in each $1 D$-reinforced specimen. Figure 7 shows the isolines of the $\mathrm{CaCO}_{3}$ content. It can be observed from Figure 7 that for each specimen, the $\mathrm{CaCO}_{3}$ content in the section $6 \mathrm{~cm}$ above the bottom was greater than that in the section within $6 \mathrm{~cm}$ of the bottom in the vertical direction, and the $\mathrm{CaCO}_{3}$ content in the section whose lower boundary was $3 \mathrm{~cm}$ above the bottom and upper boundary was $6 \mathrm{~cm}$ above the bottom was generally lower than that in other sections. In addition, the $\mathrm{CaCO}_{3}$ content of the sand specimens taken from locations near the tank boundaries was generally relatively high.

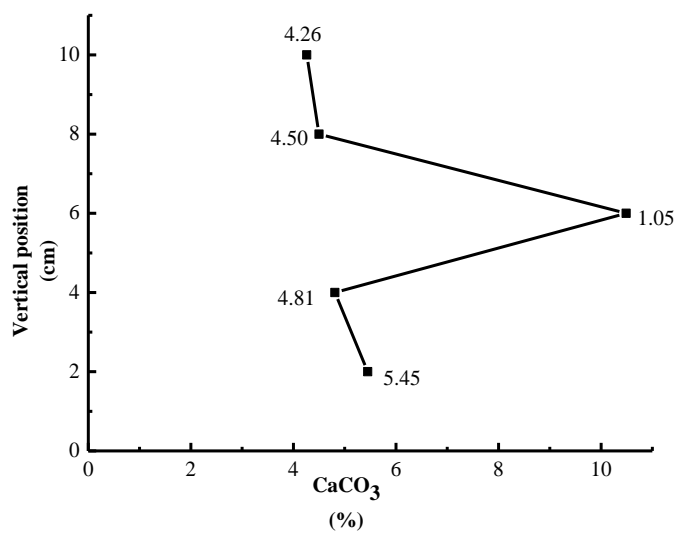

Figure 6. Figure of one-dimensional $\mathrm{CaCO}_{3}$ content

To compare the amounts of $\mathrm{CaCO}_{3}$ formed in the 1D- and 3D-reinforced sand specimens, the mean $\mathrm{CaCO}_{3}$ content of each specimen was calculated (Table 3). The mean $\mathrm{CaCO}_{3}$ content of the 1D-reinforced specimens was $4.01 \%$ (mass percentage), and the mean $\mathrm{CaCO}_{3}$ content of the 3Dreinforced specimens was $5.29 \%$ (mass percentage). Therefore, the mean $\mathrm{CaCO}_{3}$ content of the 3D-reinforced specimens was greater than that of the $1 D$-reinforced specimens.

Table 4. Microbial amount

\begin{tabular}{cccc}
\hline Test & Total amount of liquid $(\mathrm{ml})$ & Sample volume $\left(\mathrm{cm}^{\mathbf{3}}\right)$ & $\begin{array}{c}\text { Each volume of the liquid } \\
\text { dosage }\left(\mathbf{m L} / \mathrm{cm}^{\mathbf{3}}\right)\end{array}$ \\
\hline One-dimension & 307 & 235.62 & 1.30 \\
\hline Three-dimension & 2287 & 1800 & 1.27 \\
\hline
\end{tabular}

When the mean volume of the bacterial solution used was the same, the effect of the $3 D$ reinforcement treatment was superior to that of the $1 D$ reinforcement treatment, which was primarily due to the following reason: The sand specimens were not completely homogeneous. Therefore, local permeability variations occurred in both the $1 D$ and 
$3 D$ experiments. Consequently, the bacterial solution and the cementing solution injected into each soil specimen were not completely evenly distributed in the soil, resulting in a large difference in the $\mathrm{CaCO}_{3}$ content among different sections. However, compared with the $1 D$-reinforced specimens (Sonego et al., 2018), the 3D-reinforced specimens had a larger volume and more grout injection points and thus had more possible permeation paths that reached a certain reinforcement point. Therefore, the bacterial solution and the cementing solution could more evenly permeate the soil under the $3 D$ condition. Hence, the $\mathrm{CaCO}_{3}$ content was more evenly distributed under the $3 D$ condition than under the $1 D$ condition. In addition, the mean $\mathrm{CaCO}_{3}$ content formed under the $3 D$ grout injection condition was also greater than that formed under the $1 D$ grout injection condition.

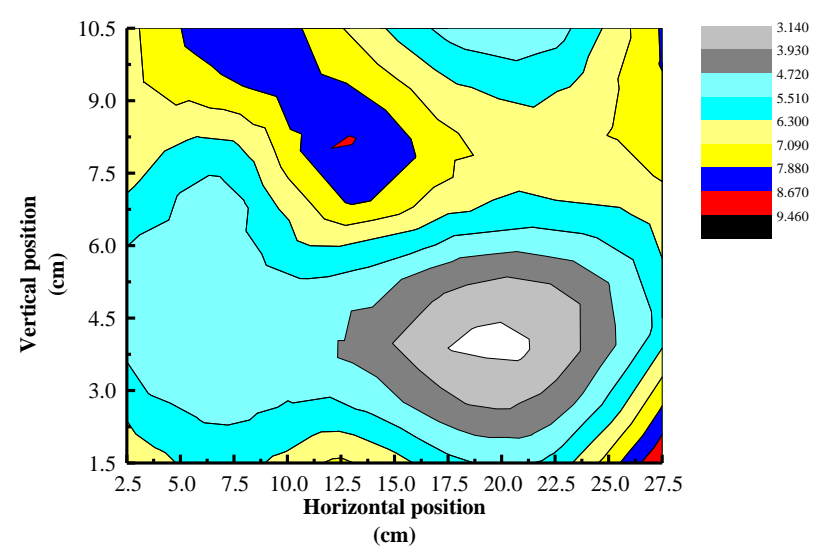

Figure 7. Contour map of two-dimensional $\mathrm{CaCO}_{3}$ content. Colors indicate $\mathrm{CaCO}_{3}$ content from < 3.14 (white) to > 9.46(black) [\% of dry weight].

\subsection{The volumes of the bacterial solution and change in the permeability coefficient}

The result of the division of the total volume of the bacterial solution by the volume of the sand specimen was used to evaluate the volume of the bacterial solution used. Table 4 lists the volumes of the bacterial solution used.

It can be observed from Table 4 that the volume of the bacterial solution used per unit volume of the sand specimen under the $1 D$ grout injection condition was $1.30 \mathrm{~mL} / \mathrm{cm}^{3}$, and the volume of the bacterial solution used per unit volume of the sand specimen under the $3 D$ grout injection condition was $1.27 \mathrm{~mL} / \mathrm{cm}^{3}$ (a $3 \%$ decrease compared with that under the $1 D$ grout injection condition). The unconfined compressive strength and the $\mathrm{CaCO}_{3}$ content of the $3 D$-reinforced specimens were greater than those of the $1 D$-reinforced specimens, and the volume of the bacterial solution per unit volume used in the $3 D$-reinforced specimens was less than that used in the $1 D$-reinforced specimens, indicating that the effect of the $3 D$ MICP grout injection method was superior to that of the $1 D$ MICP grout injection method.

There was a significant change in the permeability coefficient of both the $3 D$ - and the $1 D$-reinforced specimens. The $1 D$ sand specimens had an initial permeability coefficient of $2.17 \times 10^{-2} \mathrm{~cm} / \mathrm{s}$. After reinforcement treatment, the $1 D$ specimens had a permeability coefficient of $1.65 \times 10^{-4} \mathrm{~cm} / \mathrm{s}$, which was two orders of magnitude less than their initial permeability coefficient. The permeability coefficient of the $1 D$ sand specimens significantly decreased after the reinforcement treatment (Reeves et al., 2018). During the bacterial solution injection process, it was found that the rate at which the grout exited became increasingly lower during the late stage, indicating that $\mathrm{CaCO}_{3}$ precipitates were formed in the sand pores, which exhibited a certain "blocking" effect; this subsequently affected the permeability coefficient of the sand specimen. The mean permeability coefficient of the $3 D$-reinforced specimens was $8.65 \times 10^{-4} \mathrm{~cm} / \mathrm{s}$. While the permeability coefficient of the $3 D$ specimens decreased after the reinforcement treatment, the permeability coefficient of the $3 D$ reinforced specimens was greater than that of the $1 D$ reinforced specimens, indicating that the $3 D$ specimens had more permeation paths, i.e., the $\mathrm{CaCO}_{3}$ content of the $3 D$ specimens was greater than that of the $1 D$ specimens.

\section{Conclusions}

The present study conducted test tube and $1 D$ sand column experiments of MICP under $10-24^{\circ} \mathrm{C}$ using a ureolytic bacterium (ATCC 11859), investigated the feasibility and effect of this method under different temperature conditions in future practical engineering. The following conclusions were obtained:

The unconfined compressive strength and $\mathrm{CaCO}_{3}$ content of the $3 D \mathrm{MICP}$-reinforced specimens were greater than those of the $1 D$ MICP-reinforced specimens under the same condition. In addition, the mean volume of the bacterial solution used per unit volume of the sand specimens under $3 D$ grout injection condition was less than that under $1 D$ grout injection condition. Based on the change in the $\mathrm{CaCO}_{3}$ content throughout different sections of each specimen, we know that the $3 D$-reinforced specimens had better homogeneity than the $1 D$-reinforced specimens, indicating that the scale effect of MICP is significant. The grout injection condition in practical engineering is often $3 D$. Therefore, the limitations of using the results of $1 D$ MICP experiments to guide practical engineering should be considered.

\section{Acknowledgements}

The study presented in this article was substantially supported by National Natural Science Foundation of China (No. 51578214). The support is gratefully acknowledged.

\section{References}

Abdikadir A.O., Md. Sahadat H. and Mst. Mahmuda P. (2018), Study on Knowledge, Attitude and Practices Towards the Solid Waste Management In Karan District, Mogadishu Somalia. Environmental Contaminants Reviews, 1, 22-26.

Achille D.F. and Enow A.D. (2020), Evaluating The Bidirectional Nexus Between Climate Change And Agriculture From A Global Perspective, Malaysian Journal of Sustainable Agriculture, 4, 40-43. 
Al Qabany A., Soga K. and Santamarina C. (2012), Factors Affecting Efficiency of Microbially Induced Calcite Precipitation, Journal of Geotechnical and Geoenvironmental Engineering, 138(8), 992-1001.

Arslan Ch., Sattar A., Cuong D.M., Khan F.H., Nasir A., Bakhat Z. and Ilyas F. (2018), Study of Spatial and Temporal Variability of Arsenic in Groundwater Due to Drain by Using Gis. Earth Sciences Pakistan, 2, 22-24.

Aunsary M.N. and Chen B.C. (2019), Sustainable Water Treatment Management, Water Conservation and Management, 3, 1113.

Boquet E., Boronat A. and Ramos-Cormenzana A. (1973), Production of calcite (calcium carbonate) crystals by soil bacteria is a general phenomenon, Nature, 246, 527-529.

Cheng L. and Cord-Ruwisch R. (2012), In situ soil cementation with ureolytic bacteria by surface percolation, Ecological Engineering, 42, 64-72.

Cheng L. and Cord-Ruwisch R. (2014). Upscaling effects of soil improvement by microbially induced calcite precipitation by surface percolation, Geomicrobiology Journal, 31(5), 396-406.

Cheng L., Cord-Ruwisch R. and Shahin M.A. (2013), Cementation of sand soil by microbially induced calcite precipitation at various degrees of saturation, Canadian Geotechnical Journal, 50(1), 81-90.

Choi S.G., Wang K. and Chu J. (2016), Properties of biocemented, fiber reinforced sand, Construction and Building Materials, 120, 623-629.

De Muynck W., De Belie N. and Verstraete W. (2010), Microbial carbonate precipitation in construction materials: A review, Ecological Engineering, 36(2), 118-136.

DeJong $H_{.}$, van den Eynde F., Broadbent H., Kenyon M.D., Lavender A., Startup H., and Schmidt U. (2013), Social cognition in bulimia nervosa: A systematic review, European Psychiatry, 28(1), 1-6.

DeJong J.T., Mortensen B.M., Martinez B.C. and Nelson D.C. (2010), Bio-mediated soil improvement, Ecological Engineering, 36(2), 197-210.

Gelleh I.D., Okeke U.H., Babalogbon, Ayodeji B., Mangut Y.S. (2018), Land Suitability Analysis for The Production of Cocoyam Inbenue State, Nigeria, Earth Sciences Malaysia, 2, 25-30.

Gomez M.G., Anderson C., Graddy C.M.R., Dejong J.T., Nelson D.C. and Ginn T.R. (2017), Large-scale comparison of bioaugmentation and biostimulation approaches for biocementation of sands, Journal of Geotechnical and Geoenvironmental Engineering, 143(5), 04016124.

Hammes F. and Verstraete W. (2002), Key roles of pH and calcium metabolism in microbial carbonate precipitation, Reviews in Environmental Science and Biotechnology and Bioprocess Engineering, (1), 3-7.

Ivanov V. and Chu J. (2008), Applications of microorganisms to geotechnical engineering for bioclogging and biocementation of soil in situ, Reviews in Environmental Science and Bio/Technology, 7(2), 139-153.

Jiang N.J. and Soga K. (2017), The applicability of microbially induced calcite precipitation (micp) for internal erosion control in gravel-sand mixtures, Géotechnique, 67(1), 42-55.

Jiang N.J., Soga K. and Kuo M. (2017), Microbially induced carbonate precipitation (micp) for seepage-induced internal erosion control in sand-clay mixtures, Journal of Geotech-nical and Geoenvironmental Engineering, 143(3), 04016100.

Kang L., Du H.L., Du X., Wang H.T., Ma W.L., Wang M.L. and Zhang F.B. (2018), Study on dye wastewater treatment of tunable conductivity solid-waste-based composite cementitious material catalyst, Desalination and Water Treatment, 125, 296-301.

Liu Z. (2018), Economic analysis of energy production from coal/biomass upgrading; Part 1: Hydrogen production, Energy Sources Part B-Economics Planning and Policy, 13(2), 132136.

Liu Z. and Baghban A. (2017), Application of LSSVM for biodiesel production using supercritical ethanol solvent, Energy Sources Part A-Recovery Utilization and Environmental Effects, 39(17), 1869-1874.

Lu W., Qian C. and Wang R. (2010), Study on soil solidification based on microbiological precipitation of $\mathrm{CaCO}_{3}$, Science China-Technological Sciences, 53(9), 2372-2377.

Martinez B.C., DeJong J.T., Ginn T.R., Montoya B.M., Barkouki T.H., Hunt C., Tanyu B. and Major D. (2013), Experimental Optimization of Microbial-Induced Carbonate Precipitation for Soil Improvement, Journal of Geotechnical and Geoenvironmental Engineering, 139(4), 587-598.

Mohammad Khabir U.S., Ahmad Kamruzzaman M., Md. Zahurul H., Md. Sahadat H. and Abdullah A.N. (2019), Assessment of Inland Water Quality Parameters of Dhaka City, Bangladesh, Environment \& Ecosystem Science, 3, 13-16.

Mortensen B.M., Haber M.J., DeJong J.T., Caslake L.F. and Nelson D.C. (2011), Effects of environmental factors on microbial induced calcium carbonate precipitation, Journal of Applied Microbiology, 111(2), 338-349.

Okpoli C.C. and Iselowo D.O. (2019), Hydrogeochemistry Of Lekki, Ajah And Ikorodu Water Resources, Southwestern Nigeria, Journal Clean Was, 3, 20-24.

Ramachandran S.K., Ramakrishnan V. and Bang S.S. (2001), Remediation of concrete using microorganisms, ACl Materials Journal, 98(1), 3-9.

Rawat K.S., Kumar R. and Singh S.K. (2020), Distribution of nickel in different agro-climatic zones of Jharkhand, India, Geology, Ecology, and Landscapes, 4, 52-58

Rebata-Landa V. and Santamarina J.C. (2006), Mechanical limits to microbial activity in deep sediments, Geochemistry Geophysics Geosystems, 7.

Reeves C.J., Siddaiah A. and Menezes P.L. (2018), Tribological study of imidazolium and phosphonium ionic liquid-based lubricants as additives in carboxylic acid-based natural oil: Advancements in environmentally friendly lubricants, Journal of Cleaner Production, 176, 241-250.

Sari Y.D. (2015), Soil strength improvement by microbial cementation, Marine Georesources \& Geotechnology, 33(6), 567-571.

Sonego M., Soares Echeveste M.E. and Debarba H.G. (2018), The role of modularity in sustainable design: A systematic review, Journal of Cleaner Production, 176, 196-209.

Soon N.W., Lee L.M. and Ling H.S. (2012), An overview of the factors affecting microbial-induced calcite precipitation and its potential application in soil improvement, World Academy of Science, Engineering and Technology, 62, 723-729.

Soon N.W., Lee L.M., Khun T.C. and Ling H.S. (2013), Improvements in engineering properties of soils through 
microbial-induced calcite precipitation, KSCE Journal of Civil Engineering, 17(4), 718-728.

Van Paassen L., Ghose R., van der Linden T., van der Star W. and van Loosdrecht M. (2010), Quantifying Biomediated Ground Improvement by Ureolysis: Large-Scale Biogrout Experiment, Journal of Geotechnical and Geoenvironmental Engineering, 136(12), 1721-1728.

Whiffin V.S. (2004), Microbial $\mathrm{CaCO}_{3}$ precipitation for the production of Biocement, School of Biological Sciences and Biotechnology, Murdoch University, Perth, Australia.

Whiffin V.S., van Paassen L.A. and Harkes M.P. (2007), Microbial Carbonate Precipitation as a Soil Improvement Technique, Geomicrobiology Journal, 24(5), 417-423. 